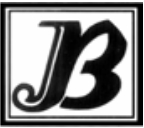

J. bio-sci. 14: 127-130, 2006

ISSN 1023-8654

\title{
TOXICITY AND REPELLANT ACTIVITY OF THREE SPICE MATERIALS ON TRIBOLIUM CASTANEUM (HERBST) ADULTS
}

\author{
K Farhana, H Islam, E H Emran and N Islam 1 \\ Department of Zoology, University of Rajshahi, Rajshahi-6205, Bangladesh
}

\begin{abstract}
The chloroform extracts of coriander (Coriandrum sativum L.), ajowain (Trachyspermum ammi (L.) Link.) and fenugreek (Trigonella foenum-grecum L.) were tested against the red flour beetle, Tribolium castaneum (Hbst.) adults through residual film assay and their repellent activity were also conducted. The $\mathrm{LD}_{50}$ values for coriander, ajowain and fenugreek were 316.173 and $243.5895,271.4573$ and 232.7095 , and 159.0106 and $4.194236 \mu \mathrm{g} / \mathrm{cm}^{2}$ for $24-$ and $48 \mathrm{~h}$ of exposure respectively. According to the intensity of activity the toxicity were found in the order of fenugreek> ajowain >coriander, while the repellent activities were in the order of fenugreek> coriander> ajowain.
\end{abstract}

Key words: Coriandrum sativum, Trachyspermum ammi, Trigonella foenum-grecum biological activity, Tribolium castaneum.

\section{Introduction}

Botanical insecticides are considered as alternatives to the synthetic chemicals for being biodegradable, pest specific, non-hazardous to human health and environment and leaving no toxic residue in nature (Periera and Wohlgemuth 1982). Plant extracts are comparatively safer to man due to their low mammalian toxicity. So, derivatives of some plants have had temporary to restricted use in pest control or have been considered items of regional interest (Saxena 1983).

Three well-known spice materials- coriander, ajowain and fenugreek seeds were taken for screening for their pesticidal activities. Chinese herbalists use coriander seeds to treat indigestion, anorexia, and stomachache. They suggest that coriander herb can be used to treat influenza in which there is no sweating. Chinese Folk Medicine uses coriander leaves and seeds to help remove unpleasant odors occurring in the genital areas of men and women, as well as halitosis or bad breath. It has antibacterial properties and is used to treat colic, neuralgia, and rheumatism. The oil counteracts unpleasant odors in pharmaceutical preparations and tobacco. It is also used in perfumes, liqueurs and gin. Coriander seeds are ground into a paste for application to skin and mouth ulcers. Before the invention of toothpaste, coriander seeds were chewed as a breath sweetener. Coriander is used in several ayurvedic remedies. Ajowain is much used as a medical plant in ayurvedic medicine. Mainly, it helps against diseases of the digestive tract and fewer. In the West, thymol is used in medicines against cough and throat irritation. Fenugreek seeds are commonly used in Bangladesh and India with the hair oil for the control of hair lice. It has a good use in the aurvedic preparations. It is also popular in the South of India and appears in the ubiquitous Tamil spice mixture sambaar podi. However, the bitter-aromatic seeds constitute an essential part of the Bengali five-spice mixture panch phorron. The reported value for the vitamins present in the seeds are: carotene $96 \mu \mathrm{g}$, thiamine $0.34 \mathrm{mg}$, riboflavin 0.29 $\mathrm{mg}$ and nicotinic acid $1.1 \mathrm{mg} / 100 \mathrm{~g}$. The seeds also contain folic acid (Anon, 1950; Kirtikar and Basu, 1935). The marketed samples of the three spice materials were collected and extracted with chloroform and the extracts were subjected to biological screening against the red flour beetle, Tribolium castaneum (Hbst.) adults through residual film assay and by repellent activity test considering their versatile potentials.

1 Corresponding author; e-mail:n_islamm@yahoo.com 


\section{Materials and Methods}

Collection and preparation of the test materials: Coriander, ajowain and fenugreek seeds were collected from the Shaheb Bazar, Rajshahi City Corporation, Bangladesh and dried in a well-ventilated room under shade from 3 to 7 days and then powdered in a hand grinder. The powdered materials were weighed and placed in separate conical flasks to add chloroform $(100 \mathrm{~g} \times 300 \mathrm{ml} \times 3$ times) and filtration was done by Whatman filter paper at $24 \mathrm{~h}$ interval in the same collection flasks. The output extracts were removed to glass vials and preserved in a refrigerator at $4^{\circ} \mathrm{C}$ with proper labeling.

Collection and culture of the test insect: $T$. castaneum used in the present experiment was reared in whole-wheat flour in the Crop Protection and Toxicology Laboratory, Department of Zoology, University of Rajshahi, Bangladesh since eight years. The flour was sterilized at $60^{\circ} \mathrm{C}$ for 24 hours in an oven. A standard mixture of whole-wheat flour with powdered dry yeast in a ratio of 19:1 (Park and Frank, 1948; Park, 1962; Zyromska-Rudzka, 1966) was used as food medium throughout the experimental period. Five hundred beetles were placed in a beaker $(500 \mathrm{ml})$ containing food medium, covered with a piece of cloth and kept in an incubator at $30 \pm 5^{\circ} \mathrm{C}$. The eggs were collected by sieving the food medium by two sieves of 500 and 250 mesh separating the adults and eggs respectively (Khan and Selman, 1981). A main culture protocol of beetles was established to get a regular supply of the newly formed adults for the experiments.

Dose-mortality test through residual film assay: The extracts were diluted separately with the solvents in which they were extracted and the actual amount of extracted matter in a dose was recorded. The other doses were prepared by serial dilution method and were used in the experiment of residual film assay. For each dose one $\mathrm{ml}$ of mixture was dropped on a petri dish $(90 \mathrm{~mm})$ in such a way that it made a uniform film over the petri dish. Then the petri dishes were air-dried leaving the extract on it. The actual extract present in one $\mathrm{ml}$ mixture was calculated and dividing the value by the area of the petri dish the dose per square centimeter was calculated. After drying 10 red flour beetles (3-5 day-old) were released in each petri dish with 3 replications. A control batch was also maintained with the same number of beetles and evaporating the solvent only. The treated beetles were placed in an incubator at the same temperature as reared in stock cultures and the mortality of the beetles was counted after 24- and $48 \mathrm{~h}$ of treatment. The extracts was selected as the stock dose while other successive doses were made by serial dilution to give 708-, 531-, 354-, 265-, 177- and 133-, for coriander 531-, 382- and 265- for ajowain and 354-, 265-, 177- and $88 \mu \mathrm{g} / \mathrm{cm}^{2}$

for fenugreek respectively. The percent mortality was subjected to statistical analysis (Finney, 1947 and Busvine, 1971). The dose-mortality relationship was expressed as a median lethal dose (LD50).

Repellent activity test: The repellency test used was adopted after McDonald et al. (1970), Talukder and Howse $(1993,1994)$. Half filter paper discs (Whatman No. 40, $9 \mathrm{~cm}$ diam.) were prepared and selected doses of $\mathrm{CHCl}_{3}$ extracts separately applied onto each of the half-disc and allowed to dry out as exposed in the air for 10 minutes. Each treated half-disc was then attached lengthwise, edge-to-edge, to a control halfdisc with adhesive tape and placed in a petri dish $(9 \mathrm{~cm}$ diam.), the inner surface of which was smeared with fluon to prevent insects escaping. Twenty adult insects were released in the middle of each filter-paper circle. Each concentration was tested five times. Insects that settled on each half of the filter paper disc were counted at $1 \mathrm{~h}$ interval for 5 hours. The average of the counts was converted to percentage repellency (PR) using the formula of Talukder and Howse (1995): $P R=2(C-50)$, Where, $C$ is the percentage of insects on 
the untreated half of the disc. Positive values expressed repellency and negative values for attractant activity. A series of doses for each of the extracts (0.75-, 0.375-, 0.1875-, 0.09375-, 0.0468-, 0.0234- and 0.01171 $\mathrm{mg}$ ) were prepared and half filter paper discs were prepared with all the $\mathrm{CHCl}_{3}$ extracts of coriander, ajowain and fenugreek seeds for repellency test. The values in the recorded data were then calculated for percent repellency, which was again developed by arcsin transformation for the calculation of ANOVA.

\section{Results and Discussion}

Insecticidal activity: The dose mortality and repellent activity results of the chloroform extracts against $T$. castaneum have been found strongly effective and the findings are given in Table 1. The tested seeds are highly significant among doses $(P<0.001)$. The intensity of dose-mortality effects found in the residual film assay the crude extracts arranged in a descending order of fenugreek $>$ ajowain $>$ coriander.

Table 1. Dose-mortality effect and repellent activity of the chloroform extracts of $C$. sativum, $T$. ammi and $T$. foenum-graecum seeds against $T$. castaneum adults for 24 - and $48 \mathrm{~h}$ of exposure.

\begin{tabular}{|c|c|c|c|c|c|c|c|c|c|}
\hline \multicolumn{5}{|c|}{ Dose-mortality effect through probit analysis } & \multicolumn{5}{|c|}{ Repellent activity through ANOVA } \\
\hline \multirow[b]{2}{*}{ Plant organ } & \multirow[b]{2}{*}{$\begin{array}{c}\text { Exposu } \\
\text { re (h) }\end{array}$} & \multirow{2}{*}{$\begin{array}{c}\mathrm{LD}_{50} \\
\text { value } \\
(\mu \mathrm{g} \\
\left.\mathrm{cm}^{-2}\right)\end{array}$} & \multirow[b]{2}{*}{$\begin{array}{c}\text { Regression } \\
\text { equation }\end{array}$} & \multirow[b]{2}{*}{$\chi^{2}$ value (df) } & \multicolumn{3}{|c|}{ Sources of variation } & \multicolumn{2}{|c|}{$\begin{array}{c}\text { F-ratio with level of } \\
\text { significance }\end{array}$} \\
\hline & & & & & $\begin{array}{l}\bar{c} \\
\Phi \\
\sum_{\mathscr{D}} \\
\infty\end{array}$ & 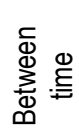 & 흔 & 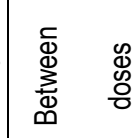 & 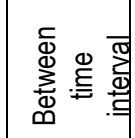 \\
\hline \multirow{2}{*}{$\begin{array}{c}\text { Seeds of } \\
\text { C. } \\
\text { sativum }\end{array}$} & 24 & 316.173 & $\begin{array}{l}Y=-2.726 \\
+3.091 X\end{array}$ & $10.787(3)$ & \multirow[t]{2}{*}{6} & \multirow[t]{2}{*}{5} & \multirow[t]{2}{*}{30} & \multirow[t]{2}{*}{$30.5354^{* * *}$} & \multirow[t]{2}{*}{0.078004} \\
\hline & 48 & $\begin{array}{c}243.589 \\
5\end{array}$ & $\begin{array}{l}Y=-4.616 \\
+4.029 X\end{array}$ & $1.992(4)$ & & & & & \\
\hline \multirow{2}{*}{$\begin{array}{l}\text { Seeds of } \\
\text { T. ammi }\end{array}$} & 24 & $\begin{array}{c}271.457 \\
3\end{array}$ & $\begin{array}{l}Y=-2.918 \\
+3.254 X\end{array}$ & $8.106 \mathrm{E}-02(1)$ & \multirow{2}{*}{6} & \multirow{2}{*}{5} & \multirow{2}{*}{30} & \multirow{2}{*}{$\underbrace{31.032784 *}_{* \star}$} & \multirow{2}{*}{${ }^{*} \underset{* *}{34.05439^{*}}$} \\
\hline & 48 & $\begin{array}{c}232.709 \\
5\end{array}$ & $\begin{array}{l}Y=-6.802 \\
+4.986 X\end{array}$ & $2.793(1)$ & & & & & \\
\hline \multirow{2}{*}{$\begin{array}{l}\text { Seeds of } \\
T . \text { foenum- } \\
\text { graecum }\end{array}$} & 24 & $\begin{array}{c}159.010 \\
6\end{array}$ & $\begin{array}{l}Y=-3.120 \\
+3.689 X\end{array}$ & $0.789(1)$ & \multirow{2}{*}{6} & \multirow{2}{*}{5} & \multirow{2}{*}{30} & \multirow{2}{*}{$\underbrace{23.71589^{* *}}_{*}$} & \multirow{2}{*}{$4.557289^{*}$} \\
\hline & 48 & $\begin{array}{c}4.19423 \\
6\end{array}$ & $\begin{array}{l}Y=-2.060 \\
+3.253 X\end{array}$ & 2.478 E-02 (1) & & & & & \\
\hline
\end{tabular}

${ }^{* * *}=\mathrm{P}<0.001 ;{ }^{*}=\mathrm{P}<0.05$

Insect repellent activity: The three extracts of $C$. sativum, $T$. ammi and $T$. foenum-graecum showed repellant activity against adult beetles of $T$. castaneum even for concentrations from 0.75 to as less as $0.01171(0.75-, 0.375-, 0.1875-, 0.09375-, 0.0468-, 0.0234-$ and 0.01171$) \mu \mathrm{g} / \mathrm{cm}^{2}$. The intensity of repellent activity had been arranged in a descending order of $T$. foenum-graecum $>C$. sativum $>T$. ammi and significant differences for time interval were found for $T$. foenum-graecum $(P<0.001)$ and for $T$. ammi $(P<0.05)$. 


\section{Acknowledgements}

This work has been carried out with the UGC grant (2003-2004) and with the Rajshahi University grant (2003-2004). The authors would like to extend their grateful thanks to the Chairman, Department of Zoology, University of Rajshahi, for providing required laboratory facilities to them.

\section{References}

Anon (1950) The wealth of India.- a dictionary of Indian raw materials and industrial products. CSIR, New Delhi, 2: 347-350.

Busvine Jr. (1971) A critical review of the techniques for testing insecticides. Commonwealth Agricultural Bureau, London, p. 345

Finney D J (1947) In: Probit Analysis: a statistical treatment of the sigmoid response curve. Cambridge Univ. Press, London. p. 333

Khan A R and Selman B J (1981) Some techniques for minimizing the difficulties I egg counting Tribolium castaneum (Herbst). Ent. Rec. Var. 93: 36-37.

Kirtikar K R and Basu B D (1935) Indian Medicinal Plants. Lalit Mohan Basu Pub. Allahabad (India) 1: 832.

McDonald L L, Guy R H and Speirs R D (1970) Preliminary evaluation of new candidate materials as toxicants, repellents and attractants against stored-product insects. Agricultural Research Service, US Department of Agriculture, Washington DC, Marketing Research Report No. 882.

Park T and Frank M B (1948) The fecundity and development of the flour beetles, Tribolium castaneum and Tribolium confusum at three constant temperatures. Ecology 29: 386-375.

Periera J and Wohlgemuth $\mathrm{R}$ (1982) Neem (Azadirachta indica A. Juss.) of West African origin as a protectant of stored maize. Z. Ang. Ent. 24(2): 208-214.

Saxena R C (1983) Naturally occurring pesticides and their potential. In: Chemistry and food supplies: The New Frontiers. Pergamon Press, Oxford, New York, 143-161.

Talukder F A and Howse P E (1993) Deterrent and insecticidal effects of extracts of pithraj, Aphanamixis polystachya (Mcliaceae), against Tribolium castaneum in storage. J. Chem. Ecol. 19: 2463-2471.

Talukder F A and Howse P E (1994) Efficacy of pithraj (Aphanamixis polystachya) seed extracts against stored-product pests. Proc. Int. Working Conf. on Stored-prod. Protec. 2: 848-852.

Talukder F A and Howse P E (1995) Evaluation of Aphanamixis polystachya as a source of repellant, antifeedants, toxicants and protectants in storage against Tribolium castaneum (Herbst) J. Stored. Prod. Res. 31(1): 55-61.

Zyromska-Rudzka H (1966) Abundance and emigration of Tribolium in a laboratory model. Ecol. Pole. A 14: 491-518. 